\title{
Fiscal Decentralization as an Instrument for Economic Development of Local Government in
} Albania

\author{
Adisa Bala PhD Cand. \\ Ministry of Internal Affairs Tirana, Albania \\ Prof.Dr. Andrea Koxhaj \\ University of Tirana Faculty of Economy
}

\begin{abstract}
A decentralized governance refers to the restructuring or reorganization of authority in order to have a system of co-responsibility between central government institutions, where regional and local level are in accordance with the principle of subsidiarity. This process aims to increase the overall quality and effectiveness of the system governance, enhancing the authority and capacities of the subnational level. One of the most critical approaches to adapt decentralization from theory into practice is its clear understanding of the concept, so be able to better predict what decentralization means, how well it can be planned and implemented, which are its implications and how the challenges can be over-comed. On the other side fiscal decentralization as a core element of financial instruments is related to the creation of opportunities for the financing of supported functions or so-called subsidized. It requires not only transferring financial resources and fiscal authority to local units, but they must be predictable in order to make planning possible enough to fulfill the tasks with transparence and autonomously. The aim of this paper is to briefly study how this process is implemented in Albania, if its principles are applied and how it has affected local government development. As it will be further described and explained, reforms made in this order have emphasized political decentralization, while the focus shifted to administrative , but not considerably into fiscal aspect.
\end{abstract}

Keywords: Local Government, Fiscal Decentralization, Financial Instrument, Economic Development

\section{Introduction}

Albania, comparing with other Western Balkan countries, has start decentralization process and reforms very late. Only in the 2000s were undertaken the first reforms of this field. The legal basis in Albania has been fragmented, therefore certain levels of governance had an unclear division of functions as well as overlapping and mixed responsibilities. On the other side, the financial aspect of this process like grants and transfers distribution to local units has been subjective. As a response, local units built a non-transparent system of their funds management, which lead to corruption and a slowdown of local economic development. The new reform of administrative and territorial reorganization is expected to give the basic results on local autonomy and financial issues. Over the last two decades, democratic decentralization has been a key element of agenda for "good governance" and has had a common goal, but the discussion of decentralization reforms should begin with the recognition of decentralization as an instrument related to economic development. Local economic development is defined in Law No.8652 / 2000 as a function of LGUs, which is at the same time a derivative of national and regional economic development policies. The way of local government financing is presented in the form of transfers intergovernmental, which are two types: Conditional and Unconditional Transfer. The first is divided by a formula that is modified almost every year and is included in the law of the state budget, the second is a transfer which mainly covers jointfunction investments. This financial dependence causes funding shortages and did not allow most LGUs to develop their local plans for the development of various economic and social projects. Within the local economic development according to the above law, these services are mainly included:

- Preparation of local economic development programs

- Establishment and functioning of public markets 
- Development of small business, through promotional activities

- Organization of services in support of local economic development

As a matter of fact, the range of services that a municipality has in its competencies with regard to local economic development is wide and includes the markets, property and services of the local economy. In a word, in local government units' functions are not only local utilities, but also domestic economic development. Local units currently have a strong dependence on central finances. This lack of local finance is not the only one that exacerbates local government in supporting local economic development plans, but as well intergovernmental transfers in order to support and cover the functions of local government.

Methodology used in this paper is generally narrative, based in our case study and strategy of decentralization, comparative analysis of indicators in different periods of time, technical criteria for the new administrative and territorial division, STAR Project, USAID Surveys. Mainly it will include reports made in our country over years. Review of documents in general regarding fiscal decentralization or reports on local economic development implied that there is a large gap in terms of local economic development plans and policy making.

\subsection{Research Methods}

Methodology used is generally narrative, based in our case study and strategy of decentralization, comparative analysis of indicators in different periods of time, technical criteria for the new administrative and territorial division, STAR Project, USAID Survey. Drivers for change were:

Fragmented local government units

- $70 \%$ of communes and $26 \%$ of municipalities comprise less than 5,000 inhabitants and $12 \%$ of communes do not count more than 1,000 inhabitants

\section{- 230 LGUs out of a total of 373 spent $60 \%$ of their budget on own staff salaries}

- 80 smallest LGUs do not provide any public service to their respective jurisdictions and communities.

General study of Local Government Units (LGUs) has been made. The situation before administrative territorial reform was implemented:

\section{LGUs Efficiency}

- 193 LGUs ( a total of 385 ) generated only $10 \%$ of own revenues

- LGU investment ratio was less than $28 \%$ of budget.

- 230 LGUs spent more than $60 \%$ of their budget on administration (operative expenditures)

- Strong dependence from state budget transfers

- High cost of public service delivery

- High administrative costs

- Strong disparities between urban and rural areas

- Weak local democracy

The new administrative-territorial Division is made up by 12 Regions (no change)and 61 Municipalities (from 373 municipalities/ communes)

Mainly the paper will include reports made in our country over years. Review of documents in general regarding fiscal decentralization or reports on local economic development implied that there is a large gap in terms of local economic development plans and policy making. 


\title{
2. Literature Review
}

This paper deals with basic concepts of decentralization and local economic development, but as well the challenge of decentralization is neither its theoretical understanding nor the lack of economic and institutional logic, but its practical implementation.

For decentralization there are many definitions that naturally relate to the principles on which it is based and to the objectives for which it is designed, but more comprehensive are the definitions given by UNDP (1997) defining it as:

\begin{abstract}
"Decentralization or decentralized governance refers to the restructuring or reorganization of authority in order to have a system of co-responsibility between government institutions at central, regional and local level in accordance with the principle of subsidiarity, increasing the quality overall and effectiveness of the governance system, enhancing the authority and capacities of the sub-national level. Decentralization can also be expected to contribute to the key elements of good governance, such as increasing the opportunities for people to participate in economic, social decisions and politics, helping to develop people's capacities and increase government accountability, transparency and accountability. "(UNDP, September 1997: 4)
\end{abstract}

Decentralization from central to local level is based on three pillars:

1. Political decentralization which aims to give citizens more power in public decision-making. This support democratization, where citiziens have more influence and their representatives in government.

2. Administrative decentralization is the transfer of institutional authority in the establishment and functioning of institutions for the performance of local functions and the provision of services.

3. Fiscal decentralization is primarily linked to the creation of opportunities for the financing of supported functions or subsidized.

\subsection{Fiscal decentralization as an instrument of local economic development}

Local economic development is a goal achieved through a strategy, which is a work plan for improving and increasing the climate of opening up new jobs through the development of enterprises and improving the quality of life. The basic proofs in favor of fiscal decentralization are (a) increase of economic efficiency through providing of better services and consequently have the advantages of proximity and information, and (b) the competitiveness and mobility of the population in local governments for the provision of public services will ensure proper matching of preferences between local communities and local governments.(Tiebout,1956)

The Maastricht Treaty describes a guiding principle "Subsidiarity Principle" for defining responsibilities among EU members. This is also a basic principle for local governance underlying the European Charter of Local Self-Government. This Charter sets out the principles regarding to the protection of the boundaries of the local authority, existence of structures and administrative resources appropriate to the tasks of local authorities, conditions under which responsibilities at local level are exercised, financial resources of local authorities, legal protection of local self-government. However the Charter does not provide an institutionalized system for controlling its implementation, in addition to requesting each country to submit all necessary information regarding legislative or other measures taken to comply with it. As described above, the institutional context of fiscal decentralization implies, above all, economic development, but there are also other different perspectives.

\section{Analysis of Decentralization Process in Albania}

The Albanian Government after the adoption of the Constitution (1998) and the enforcement of the Law "On the ratification of the European Charter of Local Self-Government" (2000) began implementing the "National Strategy of Decentralization". The Strategy had been implemented in three phases a) the immediate phase - having short-term interventions; b) a oneyear phase - where there would be legal and preparatory initiatives for the forthcoming elections $c$ ) the stage of completing the authority and the scope of competences. This strategy was an expression of the vision, consensus and common interests of the country's economic and social prosperity affirmed by the Government, local government bodies and civil society organizations. This strategy was prepared by a broad consultation supported by USAID and was drafted under the support of two political and technical structures such as National Decentralization Committee and the Decentralization 
Expert Group. The first step of this strategy was to change the legal basis that started with Organic Law 8652/2000 "On the Organization and Functioning of Local Government" and Law No. 8653 "On Administrative-Territorial Division".

Despite achievements in the last decade, Albania is far below other Central and Eastern European countries. Actually in local government we have a very serious financial situation where few municipalities have managed to cover a very small part of the functions delegated by law, are in financial difficulty. In Albania there is no law on local finances consequently this function is mainly regulated by procedural laws such as the law on tax procedures, the law on the local tax system as well as the annual budget laws.

There is a huge gap between the responsibilities of local units and financial resources.

Local finances, grants and revenues are modest for capital investment programs as an essential part of the plans. There is a tendency to steadily increase the conditional grants, affecting or impairing the coefficient of local autonomy and making the LGUs vulnerable to policy assignment approaches of funds. In recent years, the Fiscal Autonomy Index has fallen as a result of the grant's increase compared with total income.

As mentioned above, the lack of transparence, trends of corruption of local authorities regarding budget expenditures has deduct the confidence of citizens and businesses, consequently lower revenues from taxes and fees were achieved. According to legal considerations of fiscal decentralization we can assume as follows:

- Defined the main terms of the budget and finances.

- Rules / Methods / Ways to Ensure Transparency and Integrity of Local Public Finance.

- The rules on special national taxes, including the specific taxes to be allocated, the percentage transferred to local government and the procedures for transferring funds to local finances.

- Rules on unconditional transfers, including principles and formula for calculating and allocating them.

- Rules on Local Government Borrowing.

The topics on local government financial consolidation have often been part of the political debate between its various branches or between central and local government. However, the legal framework for financial resources of local government has followed in general the basic legal framework that has been drafted and adopted over the last decade and which determined the transfer of competencies and functions to local units.

\subsection{Administrative Territorial Reform consideration on fiscal decentralization}

The previous organization of the territory in 374 units of local government ( 65 municipalities and 309 communes) has led to a situation where local units where far from the attention of central government as well as their public far from services in standard and required level.

Eventhough fragmentation means an increased democracy representation which leads to a higher accountability to the public. The point is finding the necessary level of this fragmentation otherwise financial resources will not be enough and unable to implement various policies, a fact this that contradicts decentralization.

According to several studies, efficiency of service delivery is a very important argument on the context for territorial and administrative reform. By this "restructuring", opportunity to provide a better distribution of funds creates the right distribution of investments about infrastructure, social care, education, water supply service, etc. A new territory compounded by larger units ensures less inequality in income of municipalities, so central government is less likely to compensate local government units. Administrative-territorial reform was approved by Law 115/2014 adopted on 31.07.2014 "On the administrative and territorial units of local government in the Republic of Albania". The aim of this reform is to boost the efficiency of local administration, enhancing the quality of service delivery, development of territory, more authority at the local level and participatory decision-making. By these means this reform provides a good framework for local economic development and the reduction of administrative problems. It is expected to enable the effective use of funds through good management of funds, but also by tax administration and matching the needs with the financial resources. Territorial merger helps to reduce inconsistency between the areas where the services are provided. But reality comparing with theories diverges. Budget transfers has been and still is a very sensitive issue in Albania. It is a "hot potato" 
which politics holds from time to time and uses it to "cook" according to different political apetite of local units. In the name of cost reduction central government cuts transfers and funds but not always this makes economic climate very difficult for development.

In other words finding, the main challenge is the reorganization of the territory through balancing efficiency and local democracy. Reform is in the first steps and needs further interventions especially in decisionmaking, community participation and reduction of corruption.

\section{Results and Conclusions}

$\checkmark$ Financial autonomy of local government is still a challenge. Government transfers have been changing over years. local incomes and taxes are still insufficient for local units as well as their capacity. The new organizative framework must consider new strategy for fiscal reform or review the legislation.

$\checkmark$ There is an immediate need to increase the financial transfer from central government (unconditional grants) for local government.

$\checkmark$ There is a need to review the law on local borrowing in order to increase autonomy of local government by reducing Central Gov. weight in narrowing Local Autonomy. The need for macroeconomic control should not pressure local autonomy, especially the fiscal one, and hamper the power of local government initiatives.

$\checkmark$ Society, especially public positioned in local units, needs higher level of information regarding how their government is dealing with their concerns, how territorial changes are being implemented and more connection to the managerial levels responsible for them.

$\checkmark$ Reducing the fragmentation of the territory does not lead to greater capability of self management and economic development. Fiscal decentralization should accompain way along this process in order to make the administrative and territorial changes more effective.

$\checkmark$ Sub national governments should be supported to increase their ability for higher revenues and strengthen financial management. There is no discussion for local economic developement without real assigment of expenditure responsabilities, financial accountability and its monitoring.

\section{References}

Law and Regulations

[1] Law "On organization and functioning of local government" (No. 8652, 2000)

[2] Law "On territorial- administrative division of local government units in Albania (No. 115, 2014)

[3] Law "On territorial- administrative division of local government units in Albania (No. 8653, 2000)

[4] Law "On the local budget" (No. 7776, 1993) amended

[5] Law "On Local Taxes" (No.9632,2006) amended

[6] Law "On Tax Procedures in the Republic of Albania" Law " (No.9920,2008)

[7] Approved Decentralization Strategy in 2000

Journal References

[1] Bird Richard M., "Fiscal Decentralization in Developing Countries", Cambridge University Press, 1998

[2] C. Tiebout, "A Pure Theory of Local Expenditures," Journal of Political Economy, Vol. 64, No. 4, 1956

[3] European Charter of Local Self-Government, Strasbourg: Council of Europe CoE 1985

[4] Grindle, S., M., "Decentralization, Democratization and the Promise of Good Governance." New Jersey 2007.

[5] Lami R., "Formal decentralization of local governance in Albania", ojs.journals.cz

[6] United Nations Development Programme, "Fiscal Decentralization in Transition Economies: Case Studies from the Balkans and Caucasus", Bratislava, 2005 
[7] World Bank Study, Albania:" Fiscal Decentralization Study. Executive summary", Report No.27885, February 2004

Web sources:
[1] www.ccre.org
[2] www.dldp.al
[3] www.europa.eu
[4] www.financatvendore.al
[5] www.gadc.org.al
[6] www.reformaterritoriale.al
[7] www.undp.org 